\title{
Banking Literacy for New College Students in Digital Era
}

\author{
Mariana \\ Universitas Negeri Surabaya \\ Surabaya, Indonesia \\ mariana@unesa.ac.id
}

\begin{abstract}
College student as the future generation of the nation must be equipped with a variety of literacy, one of which is financial literacy. This research is a preliminary study of new college students who have just graduated from senior high school or equivalent so that they only take from the side of banking literacy. The purpose of this study is to determine the extent of knowledge and use of banking services to new college students. This research is a descriptive study which is based on a survey of new college students in accounting department 2017, amounting to 78 college students. The results of the study show that the banking literacy of new college students at Unesa Accounting Department is still low. It is hoped that after becoming a college student and obtaining economics and accounting courses, he will improve his banking literacy.
\end{abstract}

\section{Keywords - banking literacy; new college students; survey}

\section{INTRODUCTION}

College students as the future generation of the nation are required to have various knowledge and competencies. One of them is knowledge about finance or financial literacy. Broadly, financial literacy starts from having knowledge about finance, having skills in managing finances and can make financial decisions that will have a positive impact on themselves. The Financial Services Authority (OJK) has the function of organizing an integrated regulatory and supervisory system for all activities in the financial services sector. One of the strategies taken by OJK to improve public financial literacy is through education. With the socialization of financial literacy in high school and college-age adolescents, it is hoped that there will be an increase in the knowledge of the young generation towards finance. The goal is that later the younger generation will be able to make decisions, take advantage of financial products and services and not fall prey to conditions that harm themselves, such as being fooled by fraudulent investments that harm them

The results of the national financial literacy and inclusion survey conducted by OJK in 2016 the financial literacy index amounted to $29.66 \%$, up $7.82 \%$ compared to 2013 of $21.84 \%$. While the financial inclusion index in 2016 was $67.82 \%$, an increase of $8.08 \%$ compared to 2013 of $59.74 \%$. According to the Financial Services Authority (OJK) survey in 2016 the general banking literacy index occupied the top position compared to insurance literacy, pension funds and the capital market, which amounted to $28.94 \%$ in 2016 and
$21.80 \%$ in 2013. Meanwhile, the inclusion index national banking by $63 \%$ in 2016 and $57.28 \%$ in 2013 .

With the results of the second National Financial Literacy and Inclusion Survey (SNLIK) conducted by the Financial Services Authority (OJK) in 2016 which showed a financial literacy index of $29.66 \%$ and a financial inclusion index of $67.82 \%$ showed the process of educating the public about financial importance need to be improved. This figure increased compared to the SNLIK results in 2013, namely the financial literacy index of $21.84 \%$ and the financial inclusion index of $59.74 \%$. Thus there has been an increase in financial literacy (well literate) from 21.84 percent to 29.66 percent, as well as increased access to financial products and services (financial inclusion) from 59.74 percent to 67.82 percent

Financial literacy is knowledge, skills, and beliefs that influence attitudes and behavior to improve the quality of decision making and financial management in order to achieve prosperity. A person's understanding of financial literacy can be divided into four parts, namely not literate, less literate, and sufficient literate, and well literate. Financial literacy consists of literacy regarding banking, insurance, financing institutions, pension funds, and investments.

Specifically the banking literacy index increased from 21.80 percent in 2013 to 28.94 percent in 2016 . This study aims to analyze the level of banking literacy for new college students of the UNESA Accounting Department. New college students are expected to not have adequate insight into the world of banking. Thus, this study conducted a survey of the insights and use of banking services by them.

The research conducted by Chen and Volpe [1] entitled "An Analysis of Personal Financial Literacy Among College Students" aims to determine personal financial literacy among students, analyze student characteristics with financial literacy, and analyze student decisions on financial problems. The survey was conducted on 924 students from 14 universities in California, Florida, Kentucky, Massachusetts, Ohio, and Pennsylvania. The results showed that respondents had financial knowledge and could only answer $53 \%$ of questions correctly.

The results of Anastasia Sri Mendari \& Suramaya [2] study of STIE MUSI students show that from all aspects of financial literacy, both aspects of personal finance knowledge, savings and loans, insurance, and investment indicate low financial literacy. The results of the study show that from all 
aspects of financial literacy, both aspects of personal finance knowledge, savings and loans, insurance, and investment indicate low financial literacy even though education in schools has provided lecture materials related to aspects of financial literacy. This shows that learning about financial literacy in high school is not enough to provide a deep understanding of students. Knowledge about financial literacy must be given as early as possible to children so that they can apply it better in their daily lives. In addition, teaching staff in universities (lecturers) must use learning methods that are easy for students to understand.

Bhushan and Medury [3] explain financial literacy has become increasingly complex over the past few years with the introduction of many new financial products. In order to understand the risks and benefits associated with financial products, a minimum level of financial literacy has become a necessity. Individuals who have financial literacy can make effective use of financial products and services so that individuals will not be easily deceived by people who sell financial products that do not fit the individual

Technological developments, especially digital finance, entered the era of industrial revolution 4.0 emphasizing the pattern of digital economy, artificial intelligence, big data, and robotic. The era of disruption or fundamental or fundamental changes suddenly occurred in many sectors. Technology evolution and digitalization is one of the technological developments in the financial sector with many online, fintech, and start-up payment applications popping up. In the financial sector, there are many developments in the fintech market from the millennial generation. Fintech is a form of combination of the latest technology and innovation in financial service features by changing traditional methods or cultures that existed before. New college students as millennial generation need to know and understand the basic concepts of conventional banking. The function of banking as an intermediation for parties has excess funds and those who need funds. When understanding conventional practices and being transformed into digital form, students have no difficulty understanding and making decisions.

This research is a preliminary study of new college students who have just graduated from high school or equivalent so that they only take from the side of banking literacy. The hope of the author of the results of this initial survey can be continued with other literacy after students have received supportive courses, such as financial management courses and investment management. So the purpose of this study is to determine the extent of knowledge and use of banking services to new students.

\section{MethodS}

This research is a descriptive study based on a survey of the research subjects. The results of the study are expected to provide an accurate description of the level of banking literacy in new college student of UNESA accounting majors. The survey was conducted on new college students of 2017 accounting majors totaling 78 students. This study took a sample of new college students with an age range between 18-
19 years. The survey was conducted by giving 10 questions related to knowledge and understanding of banking.

\section{RESULTS AND DISCUSSION}

The young generation as the future generation of the nation must be equipped with various iterations, one of which is banking literacy. Banking literacy is the most familiar literacy in the community. In addition there is insurance literacy, investment literacy, technological financial literacy that continues to grow. Why new students need to be seen in banking literacy, because this is the basis for getting to know the next literacy. It is expected that knowing the banking literacy going forward they can increase their literacy about insurance, investment, capital markets and fintech. Good knowledge of finance will help them in the future in making financial decisions. It is expected that in the future the Indonesian generation will not be a consumptive generation, a generation that follows a lifestyle, but a generation that gets happiness and prosperity both when they are still productive and when they are not productive (retired).

Banking literacy needs to be known and understood by the younger generation, considering that in this digital era technology finance has developed in cyberspace. If students who have just graduated from high school are not equipped with banking knowledge in real terms, they can be trapped in fintech which is widely circulating in the internet world. Correct understanding of banking functions and their benefits will help new students in decision making. In this digital era, in a span of 30 minutes, customers can get a loan from Fintech. Based on data from OJK as of May 15, 2019, there are 113 registered and licensed fintech operators. Survey results in the United States $68 \%$ of the millers conduct banking processes through computers or cell phones. The growth of internet users through smart phones has increased by 70 percent. The same data also stated that the amount of new loans to GDP was still 34.77 percent. This figure reflects how big the fintech market is open.

Millennial play an important role in implementing industry 4.0 , one of which is through innovation in the fintech field. With a good understanding of banking functions, the millennial generation in this case new students is not wrong in utilizing fintech which is very easy to access.

The survey results that the author did, first about ownership of a bank account. Of 78 students, 49 students $(62.8 \%)$ already have bank accounts; the remaining 29 students $(37.2 \%)$ do not have bank accounts. This shows that they already have their own accounts and can independently use their personal accounts either to receive funds transfers from parents or for other needs. Next after they have a bank account, do they understand the rights and obligations as a customer properly? It turned out that from 78 students who understood their rights and obligations as customers there were 49 students $(62.8 \%)$ and those who did not yet have 29 students $(37.2 \%)$. This means that students who have bank accounts already know their rights and obligations. This is in accordance with the first question. This shows that before they decide to open a bank account, they already know the rights and obligations as a customer. The right as a customer utilizes 
banking services and its obligations there are administrative fees charged on a monthly basis. By knowing the rights and obligations as customers, students can make the best decisions for themselves. This is useful in making further decisions regarding insurance and investment in the future. This is good for the future, not to open a good account, insurance or securities account without knowing the rights and obligations.

On the third question about interest knowledge or profit sharing given when saves at a bank. Of the 78 students, only 9 students $(11.5 \%)$ knew the interest or profit sharing that would be obtained if they saved in the bank, the rest 69 students $(88.5 \%)$ did not know. In general, they save is not to get interest or profit sharing but savings as a means of depositing money to the bank to be safer. Besides that to facilitate transactions both for transfer or product purchases, this cannot be denied, because the interest or profit sharing given by the savings product is very small. This is relevant to the next question about the administrative fees that banks charge them as savers. Only 32 students $(41.6 \%)$ out of the 78 students knowing it and the remaining 45 students (58.4\%) did not know. It can be concluded that they do not really care about the interest or administration fees given or charged. The use of banks as a means of facilitating transactions is preferred.

Next is the ownership of an ATM card from savings to facilitate transactions and take cash as needed. Of the 78 students there were 47 students $(60.3 \%)$ who had ATMs and 31 students $(39.7 \%)$ did not have ATMs. The sixth question uses bank services to transfer to the intended account. Of the 78 students there were 58 students $(74.4 \%)$ who had used it and 20 students $(25.6 \%)$ had not used bank transfer services between banks. This shows parents giving monthly money or pocket money transfers through the bank. And some students take money through ATMs.

The seventh question knows that banks also have deposit storage services that provide higher interest rates than savings. Of the 78 students there were 44 students $(56.4 \%)$ knowing it and 34 students (43.6\%) did not know it. This knowledge will be useful for the future if they have more funds to be able to use deposits as an alternative risk-free investment. The eighth question is to use banking services using an ATM card as a payment card (debit card). Of the 78 students there were 28 students $(35.9 \%)$ knowing it and 50 students $(64.1 \%)$ did not know it. This shows that one of their backgrounds for opening a bank account is for payment needs. In the era of financial technology, almost all payments can be made online or using e-money. Debit card ownership for transaction payments is strongly influenced by the balance in savings. The amount that is less than $50 \%$ of transactions using debit cards is possible limited funds in the student's savings. Because as a student the main income is still sourced from parents, so the amount of funds in savings is still limited to daily needs. For transaction needs, the majority of students use fintech, for example the gojek application, OVO, grap for transportation and shopping needs.

The ninth question already knows that the bank has credit card services. Of the 78 students there did 72 students $(92.3 \%)$ know it and 6 students (7.7\%) did not know it. This shows that new students are familiar with credit cards whose functions are different from debit cards. Credit cards tend to provide convenience for their owners for transactions even though they do not have funds in savings. The nature of the credit card as a means of lending from the bank to the holder and is subject to interest charges. New students who know the main functions of credit cards are expected to be wise for students to use credit cards. It is because the nature of credit cards can be useful and can also build a culture of debt. Of course this is not good for the younger generation who do not have income from themselves, so it does not cultivate consumptive life.

The tenth question about the habit of saving at a bank. Of the 78 students there were 23 students $(29.5 \%)$ who had the habit of saving in banks and 55 students $(70.5 \%)$ were not used to saving money in the bank. This shows that new students know that saving money at the bank is not an attractive choice right now. The main function of banks as intermediaries shifts slightly to the temporary fund safekeeping function so that it is safe. Monthly administration costs per bank are large and interest income that is not comparable will burden the customer. So it's no longer interesting to save at the Bank. The habit of saving money for new students is also interesting to explore the reason. A saving culture is lacking or another alternative in saving. This is interesting to study further, considering the consumptive culture in the younger generation is also high. Below this is the percentage level of the answers to each question asked.

TABLE I. PERCENTAGE OF "YES" AND "NO ANSWERS

\begin{tabular}{|l|c|c|}
\hline \multicolumn{1}{|c|}{ Question } & Yes & No \\
\hline Bank account ownership & $62,8 \%$ & $37,2 \%$ \\
\hline $\begin{array}{l}\text { Rights and obligations as a bank } \\
\text { customer }\end{array}$ & $62,8 \%$ & $37,2 \%$ \\
\hline $\begin{array}{l}\text { Interest is given by the bank } \\
\text { where the savings is deposited. }\end{array}$ & $11,5 \%$ & $88,5 \%$ \\
\hline $\begin{array}{l}\text { Administrative fees charged by } \\
\text { banks to savers }\end{array}$ & $41,6 \%$ & $58,4 \%$ \\
\hline $\begin{array}{l}\text { ATM card ownership for } \\
\text { transactions and cash withdrawals }\end{array}$ & $60,3 \%$ & $39,7 \%$ \\
\hline $\begin{array}{l}\text { Use bank services to transfer to } \\
\text { the destination account }\end{array}$ & $74,4 \%$ & $25,6 \%$ \\
\hline $\begin{array}{l}\text { Knowing that banks also have } \\
\text { deposit storage services that } \\
\text { provide higher interest rates than } \\
\text { savings }\end{array}$ & $56,4 \%$ & $63,6 \%$ \\
\hline $\begin{array}{l}\text { Use banking services by using an } \\
\text { ATM card as a payment card } \\
\text { (debit card) }\end{array}$ & $35,9 \%$ & $7,7 \%$ \\
\hline $\begin{array}{l}\text { Knowing that the bank has credit } \\
\text { card services }\end{array}$ & & $70,5 \%$ \\
\hline Always save at the bank & $29,5 \%$ & \\
\hline \begin{tabular}{l} 
Source: prosed \\
\hline
\end{tabular} & & \\
\hline
\end{tabular}

Source: processed by the author

Furthermore, the authors categorize literacy into 3, namely low, medium and high. To measure the level of financial literacy adopted the research of Chen and Volpe (1998) with high financial literacy criteria if the true score exceeds $80 \%$, medium or moderate if the score is correct between $60 \%$ $80 \%$, and low if the score is correct less than $60 \%$.Correct response is categorized as low banking literacy if the respondent who answers correctly is less than $60 \%$ of respondents from 78 respondents, medium category if more than $60 \%$ of respondents up to $80 \%$ of respondents correctly answer question items, and high category if more than $80 \%$ of 
respondents correctly answer the question items. The purpose of this description is to find out on which items the respondent has good understanding and what is not. Below is a table on the level of banking literacy for new students at the Unesa Accounting Department.

TABLE II. LEVEL OF BANKING LITERACY

\begin{tabular}{|l|l|l|}
\hline \multicolumn{1}{|c|}{ Category } & \multicolumn{1}{c|}{ Amount } & Percentage \\
\hline Low & 36 & $46,2 \%$ \\
Medium & 33 & $42,3 \%$ \\
High & 9 & $11,5 \%$ \\
\hline Total & 78 & $100 \%$ \\
\hline
\end{tabular}

Source: processed by the author

Based on table 2, it can be concluded that $46.2 \%$ of new students have low banking literacy, $42.3 \%$ of new students have moderate banking literacy, and only $11.5 \%$ of new students already have high banking literacy. These results as initial information when they are new students are expected that the courses that will be obtained during lectures can improve their banking literacy.

\section{CONCLUSION}

The results showed that the banking literacy of new college students at UNESA Accounting Department was still low because the majority $(46.2 \%)$ did not fully understand banking. New college students are graduates from senior high school / vocational school equivalent, so the knowledge gained is limited to school and at home. It is hoped that after becoming a student and obtaining economics and accounting courses, he will improve his banking literacy. With good banking literacy, in this digital era college students are able to choose, determine and make decisions related to finance properly and not get caught up in things that harm themselves. So that this research needs to be followed up again after the research object has obtained several courses.

The limitations of this study only use banking literacy, not yet combined with insurance literacy, investment and technology. Future studies are expected to increase the financial literacy mix and pay attention to the demographics of the respondents.

\section{REFERENCES}

[1] H, Chen and R.P. Volpe, "An Analysis of Personal Financial Literacy among College Students", Financial Services Review, vol. 7, no. 2, pp. 107-128.

[2] P. Bhusan, and Y. Medury, "Financial literacy and its determinants", International Journal of Engineering, Business and Enterprise Applications, vol. 4, no. 2, pp. 155-160

[3] A. S. Mendari and S. S. Kewal, "Tingkat Literasi di Kalangan Mahasiswa STIE MUSI”, Jurnal Economia, vol. 9, no.2, October 2013. 